\title{
Nocardiopsis kunsanensis sp. nov., a moderately halophilic actinomycete isolated from a saltern
}

\author{
Jongsik Chun, ${ }^{1}$ Kyung Sook Bae, ${ }^{1}$ Eun Young Moon, ${ }^{1}$ Sang-Oun Jung, ${ }^{2}$ \\ Hong Kum Lee ${ }^{2}$ and Sang-Jin Kim²
}

\footnotetext{
1 Korean Collection for Type Cultures, Korea Research Institute of Bioscience and Biotechnology, PO Box 115, Yusong, Taejon 305-600, Republic of Korea

2 Microbiology Lab, Marine Biology Division, Korea Ocean Research \& Development Institute, Ansan PO Box 29, Seoul 425-600, Republic of Korea
}

Author for correspondence: Sang-Jin Kim. Tel: +82 31400 6240. Fax: +82 314062495. e-mail: s-jkim@kordi.re.kr

\begin{abstract}
A moderately halophilic actinomycete, designated HA-9', was isolated from a saltern in Kunsan, Republic of Korea, and was the subject of polyphasic identification. Analysis of 16S rDNA indicated that the isolate belonged to the genus Nocardiopsis, but differed genetically from other Nocardiopsis species. Strain HA-9 ${ }^{\top}$ contained meso-diaminopimelic acid, no diagnostic sugars, hexaor octa-hydrogenated menaquinones with 10 isoprene units, straight-chain saturated or monounsaturated, iso-, anteiso-, 10-methyl branched fatty acids with 13-18 carbons and type III phospholipids. All of these characters consistently assign the isolate to the genus Nocardiopsis. All of the validly described Nocardiopsis species, including moderately halophilic Nocardiopsis halophila, can be differentiated from the saltern isolate using morphological and physiological traits. On the basis of polyphasic evidence, the name Nocardiopsis kunsanensis sp. nov. is proposed for strain HA-9' (= KCTC 9831'), which is designated the type strain.
\end{abstract}

Keywords: Nocardiopsis kunsanensis sp. nov., polyphasic taxonomy, 16S rDNA sequencing

\section{INTRODUCTION}

The genus Nocardiopsis was created by Meyer (1976) to harbour Actinomadura dassonvillei on the basis of morphological and chemotaxonomic properties. The genus currently comprises seven validly described species, namely Nocardiopsis alba, Nocardiopsis dassonvillei, Nocardiopsis halophila, Nocardiopsis listeri, Nocardiopsis lucentensis, Nocardiopsis prasina and Nocardiopsis synnemataformans (Al-Tai \& Ruan, 1994; Kroppenstedt, 1992; Yassin et al., 1993, 1997). The members of Nocardiopsis are phylogenetically coherent and form a monophyletic clade that is equated with the family Nocardiopsaceae (Rainey et al., 1996). None of the Nocardiopsis species to date have been reported as halophilic except $N$. halophila, which can grow best at $5-15 \% \mathrm{NaCl}$ (Al-Tai \& Ruan, 1994). In this study, we report the results of polyphasic identification of an actinomycete strain, designated HA $-9^{\mathrm{T}}$, isolated from a saltern sample. The strain grew

The GenBank accession numbers for the $16 \mathrm{~S}$ rDNA sequences of Nocardiopsis kunsanensis HA-9 $\left(=\right.$ KCTC $\left.9831^{\top}\right)$ and Nocardiopsis halophila KCTC $9825^{\top}$ are AF195412 and AF195411, respectively. optimally in medium containing $10 \% \mathrm{NaCl}$ and showed properties consistent with its classification in the genus Nocardiopsis Meyer 1976 as a new species, of which the name Nocardiopsis kunsanensis sp. nov. is proposed.

\section{METHODS}

Bacterial strains. The saltern sample was collected from Kunsan, Republic of Korea. Bacterial strains were isolated by plating serially diluted samples onto Bennett medium based on seawater $(2 \mathrm{~g}$ glucose, $1 \mathrm{~g}$ yeast extract, $1 \mathrm{~g}$ malt extract, $2 \mathrm{~g}$ peptone, $20 \mathrm{~g}$ agar, 11 aged seawater, $\mathrm{pH} 7 \cdot 2$ ). After incubating at $30^{\circ} \mathrm{C}$ for 2 weeks, a visible colony, designated HA-9 ${ }^{\mathrm{T}}$, was transferred and subcultured until pure culture was obtained. Complex medium (CM; $7.5 \mathrm{~g}$ Casamino acids, $10 \mathrm{~g}$ yeast extract, $3 \mathrm{~g}$ sodium citrate, $10 \mathrm{~g}$ magnesium sulfate, $2 \mathrm{~g}$ potassium chloride, $1 \mathrm{ml} 4.98 \%$ iron sulfate, $100 \mathrm{~g} \mathrm{NaCl}, 11$ distilled water, $\mathrm{pH} 7 \cdot 4$ ) was used for growing strain HA-9 $9^{\mathrm{T}}$ and Nocardiopsis halophila KCTC $9825^{\mathrm{T}}$ (= A.S.4.1195). The strain was maintained as a glycerol suspension $(20 \%, \mathrm{w} / \mathrm{v})$ at $-80^{\circ} \mathrm{C}$.

Morphology and cultural characteristics. The cultures for morphology were prepared by incubating the test strain on $\mathrm{CM}$ agar at $37^{\circ} \mathrm{C}$ for $7 \mathrm{~d}$. The morphological properties of 
colonies, cells and spores were determined using light and scanning electron microscopes (Phillips model 515). For spore observation, the sample was fixed with glutaraldehyde, critical-point-dried, then gold-coated using the Bio-Rad SEM coating system (model E5550). Culture characteristics were observed using CM, tryptone-yeast extract, yeast extract-malt extract, peptone-yeast extract-iron, tyrosine agar, inorganic salts-starch, glycerol-asparagine (Shirling \& Gottlieb, 1966), nutrient agar (Difco) and potato-dextrose agar (Difco). All media were supplemented with $\mathrm{NaCl}$ (final concentration $10 \%, \mathrm{w} / \mathrm{v}$ ).

Physiological characteristics. All tests were done at $37^{\circ} \mathrm{C}$, unless otherwise specified. The $\mathrm{NaCl}$ requirement for growth was determined using CM supplemented with different concentrations of $\mathrm{NaCl}(0,1,3,5,10,15,20,25,30 \%)$. The temperature and $\mathrm{pH}$ ranges for growth were determined using CM. Degradation of adenine, casein, starch, hypoxanthine, tyrosine and xanthine was tested using CM as basal medium, as described by Gordon \& Smith (1955) and Gordon et al. (1974). Liquefaction of gelatin was tested using CM supplemented with gelatin $(12 \%, \mathrm{w} / \mathrm{v})$. Hydrolysis of urease was detected using basal medium $(1 \mathrm{~g}$ glucose, $1 \mathrm{~g}$ casein-peptone, $1.98 \mathrm{~g}$ disodium hydroxyphosphate, $1.51 \mathrm{~g}$ monobasic potassium phosphate, $0.5 \mathrm{~g}$ magnesium sulfate, $0 \cdot 012 \mathrm{~g}$ phenol red, $\mathrm{pH} 9 \cdot 0,11$ distilled water). Urea was filter-sterilized and added to a final concentration of $2 \%(\mathrm{w} / \mathrm{v})$. Hydrolysis of aesculin was determined using Bile aesculin agar (Difco). Growth in the presence of phenol $(0 \cdot 1 \%)$, potassium tellurite $(0 \cdot 0001 \%)$, sodium azide $(0.01 \%)$ and crystal violet $(0.0001 \%)$ was examined using $\mathrm{CM}$ as basal medium. Catalase production was assayed by using $0 \cdot 3 \%$ hydrogen peroxide with colonies taken from $\mathrm{CM}$ plates. Production of $\mathrm{H}_{2} \mathrm{~S}$ was determined using Triple-sugar iron agar (Difco). Utilization of carbohydrates as sole carbon source was examined using basal medium $(1 \mathrm{~g}$ ammonium sulfate, $7 \mathrm{~g}$ dibasic potassium phosphate, $2 \mathrm{~g}$ monobasic potassium phosphate, $0 \cdot 1 \mathrm{~g}$ magnesium sulfate, $100 \mathrm{~g} \mathrm{NaCl}, 20 \mathrm{~g}$ agar, 11 distilled water) in triplicate. Carbon compounds were sterilized by filtration and added to a final concentration of $1 \%(w / v)$. Similarly, basal medium without ammonium sulfate was used for testing utilization of substrates as sole carbon and nitrogen sources.

Chemotaxonomy. Freeze-dried biomass was prepared from $\mathrm{CM}$ broth grown at $37^{\circ} \mathrm{C}$ for $7 \mathrm{~d}$ using a shaking incubator. Analyses for diaminopimelic acid and major sugars were carried out using the procedures described by Staneck \& Roberts (1974) and Lechevalier \& Lechevalier (1970), respectively. Menaquinones were extracted from dried biomass (ca $50 \mathrm{mg}$ ), using the small-scale method of Minnikin et al. (1984), and purified preparations were examined by electron-impact MS, as described previously (Chun et al., 1997). Fatty acid methyl esters were prepared and analysed using the MIDI system (Hewlett Packard; Sasser, 1990). The presence of mycolic acids was checked by the acid methanolysis method described by Minnikin et al. (1980). Phospholipids were extracted and detected by two-dimensional TLC according to Embley \& Wait (1994).

Determination of DNA base composition. DNA was prepared according to Chun \& Goodfellow (1995). The $\mathrm{G}+\mathrm{C}$ contents of the resultant preparations were determined using the thermal denaturation method (Mandel \& Marmur, 1968).

16S rDNA analysis. The nearly complete nucleotide sequence of 16S rDNA was determined as described previously (Chun $\&$ Goodfellow, 1995). The resultant sequence of strain
HA $-9^{\mathrm{T}}$ was manually aligned with representatives of the genus Nocardiopsis and related taxa using known 16S rRNA secondary structure information. Phylogenetic trees were inferred by using the neighbour-joining (Saitou \& Nei, 1987), Fitch-Margoliash (Fitch \& Margoliash, 1967), maximum-likelihood (Felsenstein, 1981) and maximum-parsimony (Fitch, 1972) methods. Evolutionary distance matrices for the neighbour-joining and Fitch-Margoliash methods were generated according to the model of Jukes \& Cantor (1969). The trees were rooted using Actinomadura madurae (accession number X97889) as outgroup. The PHYLIP package (Felsenstein, 1993) was used for all analyses. The resultant unrooted tree topology was evaluated in bootstrap analyses (Felsenstein, 1985) of the neighbour-joining method based on 1000 resamplings.

\section{RESULTS AND DISCUSSION}

An almost complete sequence of $16 \mathrm{~S}$ rDNA was determined for isolate HA-9 $9^{\mathrm{T}}$ (1449 bp). Preliminary comparison of the sequence against the GenBank database indicated that the isolate was closely related to the members of the genus Nocardiopsis. The $16 \mathrm{~S}$ rDNA of $N$. halophila $\mathrm{KCTC} 9825^{\mathrm{T}}$ was examined, as it was not reported in the original publication (Al-Tai \& Ruan, 1994) and GenBank database. Two sequences generated in this study were manually aligned with representatives of Nocardiopsis and related taxa and the resultant phylogenetic tree is given in Fig. 1. All Nocardiopsis species, including $N$. halophila and strain HA- $9^{\mathrm{T}}$, formed a monophyletic clade that was recovered in four treeing algorithms and supported by a $99 \%$ bootstrap value. $N$. halophila formed the deepest branch within the clade and the mean sequence similarity values to other Nocardiopsis species was $95 \cdot 6 \pm 0.5 \%$. Strain HA-9 $9^{\mathrm{T}}$ formed an independent phyletic line within a monophyletic subclade containing Nocardiopsis species except $N$. halophila. The $16 \mathrm{~S}$ rDNA similarity values of the isolate to all of the Nocardiopsis species ranged from 94.6 ( N. halophila) to $97.0 \%$ ( $N$. alba, $N$. lucentensis). It is clear from phylogenetic analyses based on nearly complete $16 \mathrm{~S}$ rDNA sequences that our isolate belongs to the genus Nocardiopsis and represents a distinct phyletic line that can be equated with genomic species (Stackebrandt \& Goebel, 1994).

The membership of the isolate at the genus level was also confirmed by cell chemistry. The cell wall of isolate HA- $9^{\mathrm{T}}$ contained meso-diaminopimelic acid and no diagnostic sugars. The predominant menaquinone from the test strain was $\mathrm{MK}-10\left(\mathrm{H}_{8}\right)$, though minor amounts of MK-10 $\left(\mathrm{H}_{6}\right)$, MK-9 $\left(\mathrm{H}_{8}\right)$ and MK$9\left(\mathrm{H}_{6}\right)$ were also present. Major fatty acids found in whole-cell preparations were iso-C15:0, anteisoC16:0 and 10-methyl-C18:0. Straight-chain saturated or monounsaturated, iso- or anteiso-branched fatty acids with 13-18 carbons were also found in minor quantities. Mycolic acid was absent. The phospholipid type was type III sensu Lechevalier et al. (1977); phosphatidylcholine, phosphatidylglycerol and diphosphatidylglycerol were found, but not phosphatidylethanolamine. All of these characters consistently 


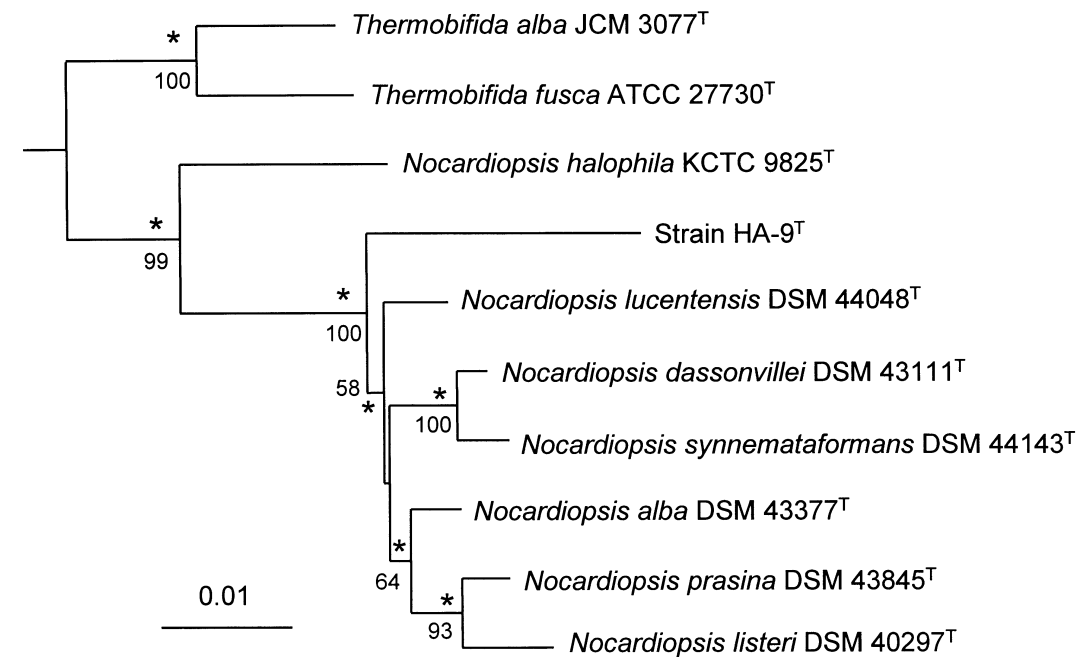

Fig. 1. Rooted neighbour-joining tree based on nearly complete $16 \mathrm{~S}$ rDNA sequences showing relationships between strain $\mathrm{HA}-9^{\top}$ and members of the genus Nocardiopsis. The numbers at the nodes indicate the levels of bootstrap support based on neighbour-joining analyses of 1000 resampled data sets; only values over $50 \%$ are given. The asterisks represent the clades that were also recovered in the Fitch-Margoliash, maximum-parsimony and maximum-likelihood trees. The scale bar indicates $0.01 \mathrm{nt}$ substitutions per nucleotide position.

place the isolate in the genus Nocardiopsis (Al-Tai \& Ruan, 1994; Grund \& Kroppenstedt, 1990; Kroppenstedt, 1992; Yassin et al., 1993, 1997). In addition, the $\mathrm{G}+\mathrm{C}$ content of the DNA was $71 \mathrm{~mol} \%$, which lies within the range for the genus.

The isolate was Gram-positive, non-acid-fast and catalase-positive. It formed circular colonies that had yellow substrate mycelia and white aerial mycelia on $\mathrm{CM}$ agar containing $10 \% \mathrm{NaCl}$. Fragmentation of mycelia was not observed. The aerial mycelia contained chains of smooth spores, which were flexible and frequently formed open loops. No pigment was produced. The test strain was able to grow in tryptoneyeast extract, yeast extract-malt extract, peptone-yeast extract-iron, nutrient (Difco) and potato-dextrose (Difco) agar, and the colour of spores was invariably white. The isolate grew on $\mathrm{CM}$ with $\mathrm{NaCl}$ concentrations between 3 and $20 \%$; no or rare growth was detected on CM supplemented 0 or $25 \% \mathrm{NaCl}$. Strain HA $-9^{\mathrm{T}}$ grew optimally at $37{ }^{\circ} \mathrm{C}$ and at $\mathrm{pH} 9$ with $10 \%$ $\mathrm{NaCl}$. No growth was observed at $\mathrm{pH}$ 5. The organism utilized D-glucose and sucrose as sole carbon source, and L-alanine as sole carbon and nitrogen source. Adenine, casein, starch, hypoxanthine, tyrosine, xanthine, gelatin and urea were degraded by the test organism. However, aesculin was not hydrolysed. It is evident from these phenotypic traits that saltern isolate HA $-9^{\mathrm{T}}$ has morphological features matching the description of the genus Nocardiopsis and exhibits a distinctive physiological pattern that differentiates it from all of valid species of the genus (Table 1).

Halophilic micro-organisms can be conveniently grouped according to $\mathrm{NaCl}$ requirements for growth (Ventosa et al., 1998). Larsen (1986) defined moderate halophiles as organisms growing optimally between 5 and $20 \% \mathrm{NaCl}$. Extreme halophiles are able to grow in saturated $\mathrm{NaCl}$ and unable to grow in the presence of $\mathrm{NaCl}$ concentrations less than $12 \%$. The occurrence of actinomycetes in highly saline environments is not rare (Gottlieb, 1973; Tresner et al., 1968). Members of the genus Actinopolyspora are either extreme or moderate halophiles (Gochnauer et al., 1975; Ruan et al., 1994; Yoshida et al., 1991). Among Nocardiopsis species, $N$. halophila is the only species that grows optimally in the presence of $5-15 \% \mathrm{NaCl}$; the trait defines the organism as a moderate halophile (Al-Tai \& Ruan, 1994). Our isolate showed similar $\mathrm{NaCl}$ requirements for growth. However, it did not grow without $\mathrm{NaCl}$ in medium, and was phylogenetically distant and exhibited different physiological characteristics from $N$. halophila and other species in the genus Nocardiopsis. While this report was being reviewed, the descriptions of two new species in the genus Nocardiopsis were published (Evtushenko et al., 2000). Both species, namely Nocardiopsis trehalosi and Norcardiopsis trop$i c a$, are not halophilic and differ from our isolate in $16 \mathrm{~S}$ rDNA sequences $(94.7$ and $96.3 \%$ similarity, respectively). Several phenotypic properties, including growth at $20 \% \mathrm{NaCl}$, can be used to separate strain $\mathrm{HA}-9^{\mathrm{T}}$ from these species. On the basis of molecular, chemical and phenotypic evidence, we propose isolate HA- $9^{\mathrm{T}}$ be classified in the genus Nocardiopsis as Nocardiopsis kunsanensis sp. nov.

\section{Description of Nocardiopsis kunsanensis sp. nov.}

Nocardiopsis kunsanensis (kun.sa.nen'sis. M.L. adj. kunsanensis pertaining to Kunsan, a location in Korea where the species was isolated).

Gram-positive, non-acid-fast, filamentous, catalasepositive and strictly aerobic. Substrate mycelia are 
Table 1. Differential phenotypic characteristics of strain $\mathrm{HA}-9^{\top}$ and other members of the genus Nocardiopsis

w, Weakly positive; v, variably utilized.

\begin{tabular}{|c|c|c|c|c|c|c|c|c|}
\hline Character & $\begin{array}{l}\text { Strain } \\
\text { HA-9 }\end{array}$ & $\begin{array}{c}\text { N. alba } \\
\text { DSM } \\
\text { 44048 }^{\mathrm{T}}\end{array}$ & $\begin{array}{c}\text { N. dassonvillei } \\
\text { DSM } \\
4^{2} 111^{\mathrm{T}} *\end{array}$ & $\begin{array}{c}\text { N. halophila } \\
\text { KCTC } \\
98225^{\mathrm{T}}\end{array}$ & $\begin{array}{c}\text { N. listeri } \\
\text { DSM } \\
40297^{\mathrm{T}} *\end{array}$ & $\begin{array}{c}\text { N. lucentensis } \\
\text { DSM } \\
44048^{\mathrm{T}} *\end{array}$ & $\begin{array}{l}\text { N. prasina } \\
\text { DSM } \\
4^{2} 845^{\mathrm{T}} *\end{array}$ & $\begin{array}{l}\text { N. synnemata- } \\
\text { formans DSM } \\
\qquad 44143^{\mathrm{T} *}\end{array}$ \\
\hline \multicolumn{9}{|l|}{ Hydrolysis of: } \\
\hline Adenine & + & + & + & + & + & + & - & + \\
\hline Hypoxanthine & + & + & + & + & + & + & - & + \\
\hline Xanthine & + & + & + & + & + & - & + & + \\
\hline \multicolumn{9}{|c|}{$\begin{array}{l}\text { Utilization as sole carbon } \\
\text { source: }\end{array}$} \\
\hline Acetate & - & - & - & - & - & + & - & - \\
\hline Cellobiose & - & + & + & $\mathrm{W}$ & - & + & - & + \\
\hline D-Galactose & - & + & $\mathrm{V}$ & + & - & - & - & + \\
\hline D-Glucose & + & + & + & $\mathrm{W}$ & - & + & - & + \\
\hline Gluconate & - & + & + & + & - & + & - & + \\
\hline$p$-Hydroxybenzoate & - & - & - & - & - & + & - & - \\
\hline myo-Inositol & - & - & - & + & - & + & - & - \\
\hline Maltose & - & + & - & + & - & + & - & + \\
\hline Mannitol & - & - & + & $\mathrm{v}$ & - & + & - & + \\
\hline Paraffin & - & - & - & w & - & + & - & - \\
\hline Raffinose & - & - & - & + & - & + & - & - \\
\hline L-Rhamnose & - & - & w & $\mathrm{w}$ & - & + & - & + \\
\hline Sucrose & + & - & + & + & - & + & - & - \\
\hline Trehalose & - & + & + & + & - & + & - & - \\
\hline D-Xylose & $\mathrm{V}$ & - & + & + & - & - & - & + \\
\hline \multicolumn{9}{|c|}{$\begin{array}{l}\text { Utilization as sole carbon } \\
\text { and nitrogen sources }\end{array}$} \\
\hline L-Alanine & + & - & + & - & - & + & + & + \\
\hline Gelatin & - & + & + & $\mathrm{V}$ & + & - & + & + \\
\hline Proline & - & + & w & + & + & + & - & + \\
\hline Serine & - & - & $\mathrm{w}$ & - & - & + & - & - \\
\hline
\end{tabular}

* Data from this and earlier studies (Yassin et al., 1997).

yellow and bear white aerial mycelia, which fragment into elongated non-motile spores with smooth surfaces. Fragmentation of substrate mycelia does not occur. No diffusible pigment is formed. Grows optimally at $37{ }^{\circ} \mathrm{C}$ and at $\mathrm{pH} 9$ with $10 \% \mathrm{NaCl}$. Does not grow on $\mathrm{CM}$ with 0 or $25 \% \mathrm{NaCl}$, nor at $\mathrm{pH} 5$. Unable to reduce nitrate to nitrite. $\mathrm{H}_{2} \mathrm{~S}$ is not produced. Utilizes D-glucose and sucrose as sole carbon source, but not acetate, cellobiose, D-galactose, gluconate, $p$ hydroxybenzoate, myo-inositol, maltose, mannitol, paraffin, raffinose, L-rhamnose or trehalose. Utilizes Lalanine, but not gelatin, proline or serine as sole carbon and nitrogen sources. Degrades adenine, casein, starch, hypoxanthine, tyrosine, xanthine, gelatin and urea, but not aesculin. Resistant to sodium azide $(0.01 \%)$, crystal violet $(0.0001 \%)$ and potassium tellurite $(0 \cdot 0001 \%)$, but not phenol $(0 \cdot 1 \%)$. Contains meso-diaminopimelic acid, no diagnostic sugars, hexaor octa-hydrogenated menaquinones with 10 isoprene units, straight-chain saturated or monounsaturated, iso-, anteiso-, 10-methyl branched fatty acids with 13-18 carbons, and phosphatidylcholine, phospha- tidylglycerol and diphosphatidylglycerol (phospholipid type III). The $\mathrm{G}+\mathrm{C}$ content of the DNA is $71 \mathrm{~mol} \%$. The species was isolated from a saltern sample collected from Kunsan, Republic of Korea. The type and only strain of Nocardiopsis kunsanensis is strain HA-9 ${ }^{\mathrm{T}}\left(=\right.$ KCTC $\left.9831^{\mathrm{T}}=\mathrm{JCM} 10721^{\mathrm{T}}\right)$.

\section{ACKNOWLEDGEMENTS}

We are grateful to Dr Soon-Ki Chae for the isolation of this strain, Professor Hans Trüper for help with nomenclature and Professor Zhiheng Liu for the gift of strain.

\section{REFERENCES}

Al-Tai, A. M. \& Ruan, J. S. (1994). Nocardiopsis halophila sp. nov., a new halophilic actinomycete isolated from soil, Int $J$ Syst Bacteriol 44, 474-478.

Chun, J. \& Goodfellow, M. (1995). A phylogenetic analysis of the genus Nocardia with $16 \mathrm{~S}$ rRNA gene sequences, Int $J$ Syst Bacteriol 45, 240-245. 
Chun, J., Blackall, L. L., Kang, S. O., Hah, Y. C. \& Goodfellow, M. (1997). A proposal to reclassify Nocardia pinensis Blackall et al. as Skermania piniformis gen. nov., comb. nov, Int J Syst Bacteriol 47, 127-131.

Embley, T. M. \& Wait, R. (1994). Structural lipids of eubacteria. In Chemical Methods in Prokaryotic Systematics, pp. 121-161. Edited by M. Goodfellow \& A. G. O'Donnell. Chichester: Wiley.

Evtushenko, L. I., Taran, V. V., Akimov, V. N., Kroppenstedt, R. M., Tiedje, J. M. \& Stackebrandt, E. (2000). Nocardiopsis tropica sp. nov., Nocardiopsis trehalosi sp. nov., nom. rev. and Nocardiopsis dassonvillei subsp. albirubida subsp. nov., comb. nov, Int J Syst Evol Microbiol 50, 73-81.

Felsenstein, J. (1981). Evolutionary trees from DNA sequences: a maximum likelihood approach, $J$ Mol Evol 17, 368-376.

Felsenstein, J. (1985). Confidence limits on phylogenies: an approach using the bootstrap, Evolution 39, 783-791.

Felsenstein, J. (1993). PHYLIP (Phylogeny Inference Package) version 3.5c. Seattle: Department of Genetics, University of Washington.

Fitch, W. M. (1972). Toward defining the course of evolution: minimum change for a specific tree topology, Syst Zool 20, 406-416.

Fitch, W. M. \& Margoliash, E. (1967). Construction of phylogenetic trees, Science 155, 279-284.

Gochnauer, M. B., Leppard, G. G., Komaratat, P., Kates, M., Novitsky, T. \& Kushner, D. J. (1975). Isolation and characterization of Actinopolyspora halophila, gen. et sp. nov., an extremely halophilic actinomycete, Can J Microbiol 21, 15001511.

Gordon, R. E. \& Smith, M. M. (1955). Proposed group of characters for the separation of Streptomyces and Nocardia, $J$ Bacteriol 69, 147-150.

Gordon, R. E., Barnett, D. A., Handerhan, J. E. \& Pang, C. H. (1974). Nocardia coeliaca, Nocardia autotrophica and the Nocardin strain, Int J Syst Bacteriol 24, 54-63.

Gottlieb, D. (1973). General considerations and implications of the actinomycetes. In Actinomycetales: Characteristics and Practical Importance, pp. 1-10. Edited by G. Sykes \& F. A. Skinner. New York: Academic Press.

Grund, E. \& Kroppenstedt, R. M. (1990). Chemotaxonomy and numerical taxonomy of the genus Nocardiopsis Meyer 1976, Int $J$ Syst Bacteriol 40, 5-11.

Jukes, T. H. \& Cantor, C. R. (1969). Evolution of protein molecules. In Mammalian Protein Metabolism, pp. 21-132. Edited by H. N. Munro. New York: Academic Press.

Kroppenstedt, R. M. (1992). The genus Nocardiopsis. In The Prokaryotes, pp. 1139-1156. Edited by A. Balows, H. G. Trüper, M. Dworkin, W. Harder \& K. H. Schleifer. New York: Springer.

Larsen, H. (1986). Halophilic and halotolerant microorganisms: an overview and historical perspective, FEMS Microbiol Rev 39, 3-7.

Lechevalier, M. P. \& Lechevalier, H. A. (1970). Chemical composition as a criterion in the classification of aerobic actinomycetes, Int J Syst Bacteriol 20, 435-443.
Lechevalier, M. P., De Bievre, C. \& Lechevalier, H. A. (1977). Chemotaxonomy of aerobic actinomycetes: phospholipid composition, Biochem Syst Ecol 5, 249-260.

Mandel, M. \& Marmur, J. (1968). Use of ultraviolet absorbance temperature profile for determining the guanine plus cytosine content of DNA, Methods Enzymol 12B, 195-206.

Meyer, J. (1976). Nocardiopsis, a new genus of the order Actinomycetales, Int J Syst Bacteriol 26, 487-493.

Minnikin, D. E., Hutchinson, I. G., Caldicott, A. B. \& Goodfellow, M. (1980). Thin-layer chromatography of methanolysates of mycolic acid-containing bacteria, J Chromatogr 188, 221-233.

Minnikin, D. E., O’Donnell, A. G., Goodfellow, M., Alderson, G., Athalye, M., Schaal, A. \& Parlett, J. H. (1984). An integrated procedure for the extraction of isoprenoid quinones and polar lipids, J Microbiol Methods 2, 233-241.

Rainey, F. A., Ward-Rainey, N., Kroppenstedt, R. M. \& Stackebrandt, E. (1996). The genus Nocardiopsis represents a phylogenetically coherent taxon and a distinct actinomycete lineage: proposal of Nocardiopsaceae fam. nov, Int J Syst Bacteriol 46, 1088-1092.

Ruan, J. S., Al-Tai, A. M., Zhou, Z. H. \& Qu, L. H. (1994). Actinopolyspora iraqiensis sp. nov., a new halophilic actinomycete isolated from soil, Int $J$ Syst Bacteriol 44, 759-763.

Saitou, N. \& Nei, M. (1987). The neighbor-joining method: a new method for reconstructing phylogenetic trees, Mol Biol Evol 4, 406-425.

Sasser, M. (1990). Identification of bacteria by gas chromatography of cellular fatty acids. Technical Note 101. Newark, Delaware: Microbial ID.

Shirling, E. B. \& Gottlieb, D. (1966). Methods for characterization of Streptomyces species, Int J Syst Bacteriol 16, 313-340.

Stackebrandt, E. \& Goebel, B. M. (1994). Taxonomic note: a place for DNA-DNA reassociation and 16S rRNA sequence analysis in the present species definition in bacteriology, Int $J$ Syst Bacteriol 44, 846-849.

Staneck, J. L. \& Roberts, G. D. (1974). Simplified approach to identification of aerobic actinomycetes by thin-layer chromatography, Appl Microbiol 28, 226-231.

Tresner, H. D., Hayes, J. S. \& Backus, E. J. (1968). Differential tolerance of streptomycetes to sodium chloride as a taxonomic tool, Appl Microbiol 16, 1134-1136.

Ventosa, A., Nieto, J. J. \& Oren, A. (1998). Biology of moderately halophilic aerobic bacteria, Microbiol Mol Biol Rev 62, 504-544.

Yassin, A. F., Galinski, E. A., Wohlfarth, A., Jahnke, K. D., Schaal, K. P. \& Trueper, H. G. (1993). A new actinomycete species, Nocardiopsis lucentensis sp. nov, Int $J$ Syst Bacteriol 43, 266-271.

Yassin, A. F., Rainey, F. A., Burghardt, J., Gierth, D., Ungerechts, J., Lux, I., Seifert, P., Bal, C. \& Schaal, K. P. (1997). Description of Nocardiopsis synnemataformans sp. nov., elevation of Nocardiopsis alba subsp. prasina to Nocardiopsis prasina comb. nov., and designation of Nocardiopsis antarctica and Nocardiopsis alborubida as later subjective synonyms of Nocardiopsis dassonvillei, Int J Syst Bacteriol 47, 983-988.

Yoshida, M., Matsubara, K., Kudo, T. \& Horikoshi, K. (1991). Actinopolyspora mortivallis sp. nov., a moderately halophilic actinomycete, Int J Syst Bacteriol 41, 15-20. 